\title{
LER O TEXTO, FITAR A IMAGEM
}

\author{
READ TEXT, STARE IMAGE
}

Julia Scamparini'

RESUMO: A partir da perspectiva do leitor será analisado o uso de fotografias no romance Divórcio, de Ricardo Lísias. Parte-se da premissa de que imagens técnicas, ao serem impressas num livro classificado como romance, ou seja, num dispositivo literário, operam uma transgressăo, no sentido iseriano (2013), trazendo à tona as colisóes entre o real e o ficcional, atual "mania" das artes como um todo. Esta cristalizaçáo do fazer ficcional parte do caráter autobiográfico do romance e chega nas fotografias, lidas inicialmente como documentos históricos, consequência de uma orientaçăo cognitivo-antropológica da recepçấo. As fotografias comparecem, assim, como elementos ambíguos, que chamam atençâo nâo só para sua imagem como também para seu meio, isto é, a fotografia enquanto dispositivo, e tudo o que ela representa contemporaneamente, ou seja, fora de um romance.

Palavras-chave: autoficçấo; recepçâo; Fotografia.

ABSTRACT: This paper aims at analyzing the use of photographs in novel Divórcio, by Brazilian writer Ricardo Lísias, from the point of view of the reader. Our basic premise is that technical images, when displayed in a book classified as a novel, thus, a literary device, operate a transgression in the Iserian sense (2013), bringing about a clash between real and fictional - this being a current trend in the arts on the whole. Such crystallization of the fictional rendering starts with the autobiographical nature of novels until it reaches photographs, initially read as historical documents as a consequence of a cognitive-anthropological orientation in reception. Therefore, photographs become ambiguous elements, which attract attention not only as images, but also as media, that is to say, photographs as devices, as well as everything they encompass and represent contemporarily, in other words, apart from the novel they were originally attached to.

Keywords: autofiction; reception; Photographs.

Pós-Doutora pela Universidade Federal Fluminense. Coordenou o Laboratório de Imagem e Som (lis. uff.br). Professora Adjunta da Universidade do Estado do Rio de Janeiro (UERJ). Tradutora de italiano. Pesquisadora do discurso e da subjetividade nas mídias literatura e cinema. 
"Que vaidade a da pintura, que atrai a admiraçâo pela semelhança das coisas de que nâo se admiram os originais."

Blaise Pascal

Em uma das primeiras aulas de um curso de Literatura Italiana I, cuja etapa mais importante seria a introduçâo à obra de Dante Alighieri, os alunos, ao serem indagados sobre os conhecimentos que tinham sobre a Divina Comédia, disseram ser a imagem do inferno dantesco a informaçáo mais proeminente da obra. Pelo fato de eu ter tomado a Comédia como objeto de análise como professora, o que me fez selecionar e organizar muitos aspectos de sua riqueza literária, confesso que me surpreendi. Alunos de Letras, do curso de Italiano, encantados com a cultura da península, a informaçăo primeira que desponta de seu imaginário com respeito a um dos livros mais importantes da História da Literatura é uma imagem mental construída de palavras nunca lidas e também de imagens nunca vistas.

O que esculpe a fantasia sobre esta abstraçăo que é o inferno dantesco é uma rede discursiva que tomou vida própria; esta poderia ser uma das respostas a minha inquietaçâo acima descrita. Uma rede discursiva que independe de origem e representaçóes materiais, mas que nâo prescinde do aspecto ficcional: a sustentaçấo de imagens vinculadas à literatura, da imagem mental ou abstrata que povoa a memória e a imaginaçăo das pessoas talvez seja a ficçăo. Ficçăo que se instala no real năo como presença em matéria, mas como existência ausente, fantasma de um morto desconhecido, um "inexistente visualizado como se fosse realidade" (ISER, 1996, p. 73), ou seja, uma realidade virtual:

O discurso poético é um processo cruzado, e se compóe de duas espécies de sons: a primeira é uma espécie de mudança - que nós podemos ouvir e perceber dos instrumentos próprios do discurso poético, que emergem a partir do ímpeto do discurso; a segunda é o discurso vero e proprio, ou seja, a atividade que, no plano da entonaçấo e da fonética, é desempenhada por tais instrumentos. Concebida nestes termos, a poesia năo é uma parte da natureza - seria sua parte melhor, aquela eleita - e é ainda menos um seu espelhamento, o que se traduziria em um desprezo do princípio de identidade; mas com espantosa independência essa se instala em um campo de açóes novo, extra-espacial, comprometendo-se náo tanto a contar, mas sobretudo a recitar a natureza, através dos meios instrumentais denominados vulgarmente imagens. (MANDELSTAN, 2015, p. ???)

Ao discorrer sobre a Divina Comédia, o poeta russo Osip Mandelstan parece explicar, nesta citaçáo, o processo que antecede e também é posterior à poesia - o qual estendemos à ficçăo como um todo, neste trabalho: a natureza năo é intrínseca à poesia, mas através de imagens ela age sobre o mundo natural. A extensâo do campo de açôes que o grande poema dantesco visita é inimaginável, mas certamente congrega imagens mais ingênuas, como aquela dos alunos de literatura italiana, bem como leituras mais informadas e preparadas para enfrentar toda a complexidade literária, filosófica, transcendental da Divina Comédia. No entanto, sem querer, estes alunos "ingênuos" foram responsáveis por me reorientar e lembrar que literatura é também imagem. 
Em outro curso de literatura, que versava desta vez sobre obras contemporâneas, mais precisamente sobre narrativas autobiográficas literárias e fílmicas - quando discutimos questôes concernentes à autoficçăo como escrita de si -, a heterogênea experiência de leitura dos alunos foi motivo de conflito entre o grupo. Todos lemos o romance Divórcio, de Ricardo Lísias, que agradou a alguns e gerou indignaçâo a outros. "Como pode este romance ter sido publicado?" foi uma das perguntas feitas pelo aluno de formaçăo mais abrangente do grupo. De fato, o romance de Lísias rompe paradigmas literários e causa estranhamento, mas, pelo mesmo motivo, tornou-se sucesso de público e, quase sempre, da crítica. É uma obra autoficcional, com coincidência entre autor e narrador-personagem, bem como outras características do gênero, como a circularidade (ou năo adesâo) dos regimes ficcional e biográfico.

Estes dois relatos de experiência podem ser apreendidos como ilustraçóes da recepçăo de uma obra por seus leitores. Recepçăo que engloba uma miríade de fenômenos que incluem a leitura stricto senso da obra e que também prescinde dela e que, portanto, a considera como elemento gerador de efeitos no mundo. Esses efeitos năo săo somente estéticos, uma vez que um livro se torna emblemático do conjunto da obra de um autor, como no caso do trabalho de Ricardo Lísias, ou ganha vida discursiva, como é o caso da Comédia. Em se tratando de duas narrativas completamente díspares em quase todos os sentidos (temporal, de gênero, de corpulência histórica, etc.), pouco as acomuna, como, talvez coincidentemente, o fato de se tratarem de obras em que autor e narrador-personagem coincidem. No entanto, olhadas em paralelo por intermédio dos relatos acima descritos, permitem a interpretaçáo de que o discurso erigido sobre elas é resultado de um processo muito complexo que inclui o texto em si, sua leitura, a crítica e, principalmente, em nosso caso, o que elas fazem com respeito a imagens, e como isso chega ao receptor.

O uso do termo imagem năo se filia aqui a uma corrente única de pensamento, pois as inquietaçóes que movem este ensaio partem da imagem mental de um livro, a Divina Comédia, e chegarăo ao uso de imagens fabricadas em outro, o romance Divórcio. Seu ponto de encontro é a adoçâo da perspectiva do leitor, e a tentativa de articulaçáo do pensamento de teóricos da literatura, da imagem e da linguística para uma reflexâo acerca das relaçóes entre imagem e fotografia.

Hans Belting e sua antropologia da imagem apontam para uma acepçăo bastante elucidadora respondendo a algumas perguntas, tais como: onde está a imagem? Está em nosso olhar ou apenas em nossa memória, e até em que grau ela está no impresso? Sua perspectiva antropológica procura entender o que é uma imagem, apesar de náo apresentar sobre o assunto um conceito conclusivo (e redutor). O que se compreende, grosso modo, é que a imagem transita entre uma aparência abstrata e um meio em que ela se realiza. O meio originário da ideia de imagem teria sido o corpo de um ser, cuja aparência se destacou quando da morte deste ser: na antiguidade, as estátuas ou inscriçóes de pessoas mortas deram origem a um pensamento sobre a imagem, justamente porque apresentaram ao mundo a aparência de um ser materializada em outro meio que năo o corpo:

O corpo vivo que, ao mesmo tempo, é potência para as vidas exterior e interior da imagem, é também meio, pois incorpora a imagem do ser. Isso fica mais evidente com a morte, quando, para se manterem visíveis, as imagens devem se corporificar através de outro meio, tornando "uma ausência visível ao transformá-la em uma nova forma de presença". (BELTING, 2005, p. 69) 
Uma imagem náo serve à verdade do mundo e nâo é a sequência do objeto, diz, no entanto, Blanchot (2011). Se o cadáver é a imagem do ser, antes da morte, ser e imagem estavam conjugados, ou seja, a imagem náo surge após o objeto, mas vive a despeito do mesmo e pode ser descrita como a sua aparência: o ser do objeto aparece quando ele quebra, e o objeto quebrado se torna imagem. Para Blanchot (ibid., p. 283), "só aparece o que se entregou à imagem, e tudo o que aparece é, nesse sentido, imaginário".

A imagem, portanto, "flutua entre a existência física e a mental: ela pode viver em uma obra de arte, mas náo coincide com ela" (BELTING, 2005, p. 66). A literatura torna-se, entâo, um campo propício à formaçăo e à vida de imagens justamente porque é um meio que năo as concretiza visualmente, mas simbolicamente através de palavras e combinaçōes de palavras. As imagens com as quais lida a literatura - selecionadas do real e recombinadas no texto - sâo da ordem do imaginário, "imagens que vivem apenas em nosso pensamento e imaginaçaáo" (ibid., p. 72). Ou seja, săo imagens sem corpo, pois nâo têm materialidade visual para além da conceptualizaçăo mental, simbólica, e nem mesmo se materializam visualmente na mídia livro - o que acaba por servir como impulso para um desejo de materializaçáo dessas imagens, que pode ser satisfeito com as adaptaçôes fílmicas, por exemplo. Para Belting, o entendimento da questăo através da tríade imagem-corpo-meio interessa por conta de sua perspectiva antropológica: "As imagens acontecem entre nós, que as olhamos, e seus meios, com os quais elas respondem ao nosso fitar. Elas se fiam em dois atos simbólicos que envolvem nosso corpo vivo: o ato de fabricaçăo e o de percepçâo, sendo este último o propósito do anterior" (ibid., p. 69).

O meio físico que a literatura nâo é para as imagens acaba por tornar o meio (da tríade de Belting) a própria percepçâo humana, que as "materializa" no plano das ideias. Através da ficçăo literária, fabricam-se imagens mentais para a nossa percepçâo do/no mundo, para que as concebamos individualmente a partir de conhecimentos simbólicos partilhados, que sáo a sua "origem". Ou seja, uma hipótese é que a tríade de Belting, pensada para as imagens e sua visibilidade, quando aplicada à literatura, transfigurese em imagem-corpo-imaginário.

Em outras palavras, no que diz respeito à literatura, as imagens normalmente mantêm-se como fato interior, pois náo se tornam visíveis. Da imagem literária, ou seja, do imaginário, presença impalpável, elemento sustentador e relaçăo apriorística da interaçâo entre obra e leitor, para a imagem fabricada para a literatura, existente em uma mídia literária (o livro), o percurso analítico (e teórico) pode ser vastíssimo, ${ }^{2}$ e pode tomar como objeto as imagens que povoam os livros como ilustraçóes; como elemento artístico que acompanha (mas năo ilustra) o discurso verbal; mas, quando se tratam de imagens técnicas, pedem outro tipo de análise e de leitura, pois concebemos, ainda que instintivamente, imagens fabricadas pelo homem (pintura, gravura, desenho) e imagens técnicas (fotografia), das quais o homem aparece como intermediário entre cena e câmera, de forma muito diferente.

A fotografia é o meio em que o entendimento da relaçâo entre imagem e morte é mais claramente traduzido, pois a figura fotográfica é ícone do ser, é o duplo sem

Para um panorama que inclui outras referências teóricas e críticas, cf.: RÍOS, Valeria de los. Analogías: fotografía y literatura en Mario Bellatin. Disponível em: 〈https://trans.revues.org/1089\#text〉. Para uma discussăo sobre o real na literatura, cf.; HORNE, Luiz. Literaturas reales: transformaciones del realismo en la narrativa latino-americana contemporánea. 
vida, uma micro-experiência da morte, segundo Roland Barthes em A câmara clara. A banalizaçáo do uso da fotografia, no entanto, esconde do observador desatento seja seu caráter de duplo, a reflexăo sobre a imagem descolada do corpo "morto", e mesmo qualquer pensamento sobre o instante, o registro, o recorte, a historicidade, dentre as muitas possibilidades de reflexăo acerca de um meio ainda novo na história da humanidade. Essa banalizaçăo interrompe-se quando do uso artístico da fotografia. No caso do romance Divórcio, as fotografias comparecem num território que năo lhes é próprio, e fazem com que, em um primeiro momento, como leitores, as concebamos como discurso de apoio à narrativa, sem que muita atençăo lhes seja pedida (pelo texto) ou dedicada (pelos leitores).

Nâo obstante a vastidăo do pensamento filosófico e teórico sobre a fotografia, a relaçăo do homem com este dispositivo é histórica e cognitivamente direcionada a uma percepçăo realista da cena captada pela câmera. Assim, ainda que inseridas em uma obra de ficçăo, a leitura do observador é orientada instintivamente a tomá-las como documento, principalmente quando as fotografias sâo estética e discursivamente dadas como históricas. O preto e branco e a qualidade precária da imagem fotográfica, por exemplo, servem normalmente a um padrăo estético-temporal que instaura uma ambiência específica de tempo passado e distante; e as posiçóes, vestimentas e mesmo expressōes faciais podem também viajar para um tempo em que a postura corporal dos fotografados era mais posada, menos natural. As fotografias presentes em Divórcio săo esteticamente assim, e os leitores de uma obra autoficcional que lança mâo de fotos históricas săo levados a lerem-nas nesta chave, pois a percepçăo visual é determinada por uma leitura sócio-histórica do homem com as imagens técnicas.

A experiência de leitura de uma obra literária foi alvo de interesse do teórico alemăo Wolfgang Iser (1996-2013), na época procurando escapar de uma forma de analisar a literatura que fosse essencialmente hermenêutica, ou seja, ancorada nos sentidos presentes no texto literário. Sua contribuiçăo contempla uma teoria do efeito estético e uma estética de recepçăo, a primeira mais voltada à formulaçăo dos textos e a segunda direcionada ao leitor. Em ambas as conceituaçôes as instâncias obra e leitor têm fundamental papel, uma vez que a base da proposta é justamente a interaçáo entre o objeto (o texto) e o sujeito (o leitor) - que năo devem ser vistos desta forma binária se nos filiamos ao seu pensamento; antes, devem ser entendidos como instâncias de um ato comunicativo em que outros elementos também jogam, como os atos de fingir e o real, para construir uma espécie de năo-dito de fundamental importância e responsável pela uniăo do todo: o imaginário.

Para compreender e explicar o que é o seu leitor implícito, Iser (1996) conduz a uma investigaçăo (auto)crítica que parte de outros teóricos (pp. 67-72) e desemboca em sua proposta:

Ele [o romance] tem uma estrutura perspectivista que compóe-se de algumas perspectivas principais que podem ser claramente diferenciadas e săo constituídas pelo narrador, pelos personagens, pelo enredo e pela ficçâo do leitor. Qualquer que seja a posiçăo dessas perspectivas do texto na hierarquia, nenhuma delas se identifica exclusivamente com o sentido do texto. Ao contrário, elas marcam em princípio diferentes centros de orientaçăo no texto, que devem ser relacionados, para que se concretize o quadro comum de referências. A tal ponto uma certa estrutura textual é 
estabelecida para o leitor que ele é obrigado a assumir um ponto de vista que permita produzir a integraçâo das perspectivas textuais. O leitor, porém, náo pode escolher livremente esse ponto de vista, pois ele resulta da perspectiva interna ao texto. Só quando todas as perspectivas do texto convergem no quadro comum de referências o ponto de vista do leitor torna-se adequado. Embora já năo sejam eles representados no texto, ponto de vista e quadro de referências resultam da construçăo perspectivística do texto. É justamente por esse motivo que o leitor ganha a oportunidade de assumir o ponto de vista que é proporcionado pelo texto, para que se constitua o quadro de referências das perspectivas textuais. Daí resulta o esquema elementar do papel do leitor delineado no texto. Esse papel exige de cada leitor que assuma o ponto de vista previamente dado; só assim ele conseguirá captar as perspectivas divergentes no texto e juntá-las no sistema de perspectividade. Daí se infere o sentido daquilo que é representado em cada uma das perspectivas. (ISER, 1996, p. 74)

Algumas páginas adiante, Iser argumenta que há um encontro entre o ponto de vista do observador, interno à obra, considerado pelo artista em seu trabalho, como acima descrito, e a atençăo do observador, que é levado a buscar tal ponto de vista na obra.

Tal ponto de vista situa o leitor no texto; deste modo, ele consegue constituir o horizonte de sentido, ao qual é conduzido pelas perspectivas matizadas no texto. Mas como o horizonte do sentido nem copia algo dado do real, nem do hábito de um público intencionado, o leitor deve imaginá-lo. Apenas a imaginaçăo é capaz de captar o năo-dado, de modo que a estrutura do texto, ao estimular uma sequência de imagens, se traduz na consciência receptiva do leitor. O conteúdo dessas imagens continua sendo afetado pelas experiências dos leitores. Essas experiências constituem o quadro de referências que permite apropriar-se do náo familiar ou ao menos fundamentar sua imagem. A concepçăo do leitor implícito descreve, portanto, um processo de transferência pelo qual as estruturas do texto se traduzem nas experiências do leitor através dos atos de imaginaçăo. (ISER, 1996, pag. 79)

Iser conclui esta passagem afirmando que tal estrutura serve para todos os textos ficcionais, e, portanto, assume um caráter transcendental. Com o objetivo de descrever esta trama, o teórico alemáo percorrerá o acontecimento da leitura, em busca de uma estética dos efeitos que culminará em seu estudo sobre o fictício e o imaginário (2013). Neste, defende que para erigir uma narrativa ficcional opera-se através de uma tríade - real-fictício-imaginário - e que, para que haja a ficçăo, é preciso passar pelas etapas de seleçăo, combinaçăo e autoindicaçăo. Em poucas palavras, a tríade funciona desta forma: o real é a matéria-prima de onde retiram-se temas, impressóes, inspiraçóes, sendo que os campos de referência do que será selecionado sâo de natureza sociocultural, bem como de natureza literária: "A seleçâo é uma transgressăo de limites, na medida em que os elementos acolhidos pelo texto agora se desvinculam da estruturaçâo semântica ou sistemática dos sistemas de que foram tomados". Ainda mais importante, a seleçâo "retira-os desta identificaçăo e os converte em objetos da percepçăo" (ISER, 2013, p. 35). A operaçăo seguinte é a de combinaçăo, quando entram em jogo os elementos textuais e verbais que reformularăo os elementos selecionados. Finalmente, o texto apresenta-se como se, isto é, ao mesmo tempo em que assume sua ficcionalidade, apresenta-se como se fosse real: 
O sinal de ficçăo no texto assinalado é antes de tudo reconhecido através de convençôes determinadas, historicamente variadas, que o autor e o público compartilham e que se manifestam nos sinais correspondentes. Assim, o sinal de ficçâo nâo designa nem mais a ficçáo como tal, mas sim o "contrato" entre autor e leitor, cuja regulamentaçăo comprova o texto năo como discurso, mas sim como discurso encenado. (ISER, 2013, p. 42)

Sendo o como se aceito pelo leitor, o imaginário torna-se a base em que se encontra o fictício - termo que contempla a parcela mais estrutural do texto, isto é, sua materialidade verbal e os elementos do conhecimento comum em que se ampara para, depois, voltarem ao mundo como "novidade". Real, fictício e imaginário săo indissociáveis, mas tornam-se categorias de análise que funcionam para que flertemos com algo que nâo nos é totalmente apreensível: o que temos feito com as imagens e a literatura e, sobretudo, o que a literatura e as imagens podem nos propor.

Se arriscamos colocar em paralelo a tríade de Belting (imagem, corpo, meio) com a tríade de Iser (real, fictício, imaginário), a imagem e o real podem ser tomados, juntos, como imagens cognitivamente idealizadas, isto é, que sáo coletivamente compartilhadas e, ao mesmo tempo, concebidas de forma individual, o que é inevitável; o corpo é o fictício, potência que organiza o conhecimento compartilhado retirado do mundo e o remodela individualmente; e o meio em que uma imagem se concretiza é, na literatura, o imaginário, conforme já acenado, solo imaterial, mas que imprime sua presença no mundo através da leitura e das novas possibilidades de percepçâo que com ela se realizam.

Fitar uma imagem visível equivale, portanto, a ler uma imagem mental? Certamente, năo. O entendimento de imagens por meio da figura e do verbo se realizam corporalmente de forma diversa, pois uma depende do recurso da visualidade e outra depende do recurso da linguagem, ambos aparatos distintos da cogniçấo humana, mas sem os quais năo conseguiríamos nem mesmo nos entender no mundo como seres humanos. O que nos interessa é aproximar as formas de se teorizar sobre imagem para que possamos alcançar um entendimento maior com respeito ao que a literatura faz a partir de e/ou com imagens, e, para tanto, parte-se de uma perspectiva do receptor para que possamos lançar a hipótese de que novos meios, dispositivos ou tecnologias podem alterar formas de percebermos a própria literatura.

Segundo Mittelberg (2013), num estudo cognitivo sobre a recepçăo das obras de Paul Klee, a relaçâo entre os observadores e os quadros é estudada a partir de um esquema imagético de equilíbrio: uma experiência corporal humana que se desdobra, através de um esquema imagético e de uma dinâmica de forças, em três obras de Klee. Em se tratando de obras náo realistas, ao fitar a imagem, os observadores organizam o visível náo a partir de uma busca por sentidos, mas relacionam-se com ela através do equilíbrio nelas instalados - consequência de uma concepçâo humana da qual o artista năo prescinde - o qual retorna aos observadores de modo também corporificado, conforme comprova o estudo. Como se regras elementares de nossa percepçăo fossem responsáveis pela relaçăo com o visível, e também, consequentemente, pela forma como vemos (e realizamos) obras de arte.

No estudo "A pintura de Manet" (2010), vemos que chamou a atençăo de Foucault um padrăo de pinturas de Édouard Manet que interfere no observador de forma 
semelhante. Seu estudo năo passa por análises da cogniçăo ou pelo equilíbrio, mas a atençăo do filósofo leva a uma leitura análoga: o ponto de vista da visualidade padrăo é rompido e propóe uma torçấo, ainda que os quadros de Manet tenham caráter mais realista do que as pinturas de Klee. Em Manet, o observador é levado ao incômodo porque o artista rompe com regras de percepçăo básica, baseadas na perspectiva da pintura realista, e desloca o observador a partir de determinaçōes pictóricas inseridas no quadro, que redefinem sua postura corporal para a elas responder. Ou seja, o que se conclui a partir destes dois estudos é que o observador de uma imagem a vê de uma forma cognitiva e corporalmente orientada, bem como tem sua percepçăo afetada por ela, quando a mesma rompe com modelos pré-definidos culturalmente, inspirados na natureza humana.

Algumas obras recentes têm trazido para a literatura inquietaçôes acerca da relaçâo entre o real e o fictício, e é nesta confusâo que se fundamentam as obras autoficcionais. Ou melhor: quando da perspectiva do leitor, a análise de um romance autoficcional faz adotar a noçâo de pacto - biográfico e/ou ficcional - como imprescindível. É esta a característica que difere romances memorialistas e a Divina Comédia, entre tantos outros casos, do que hoje se concebe por autoficçăo. O conceito passa por uma indistinçăo entre um pacto ficcional e um pacto autobiográfico, que na tradiçăo foram cruciais para os gêneros ficçăo e biografia. Hoje, a mescla e a ambiguidade entre estes regimes é o que caracteriza um novo gênero, na literatura, e se prolifera em outras artes, narrativas ou năo. Assim, realocado para um novo campo que redefine o espaço literário, o leitor precisa se adaptar a um regime novo de leitura, que năo se define entre realidade ou invençăo.

Quando imagens fotográficas adentram a autoficçăo literária, a problemática se expande. No romance Divórcio, há dez fotografias de família, sendo que somente algumas săo identificáveis como pertencentes à família do autor do livro, pela semelhança entre o rosto da criança que figura nas imagens e o rosto do escritor. Săo imagens em preto e branco, domésticas, afetivas, mas que nâo sâo descritas verbalmente, nem mesmo comentadas no texto. Podem passar despercebidas, ou podem levar a uma postura específica, de desejo pelo desvendamento do que a foto faz ver.

Logo após a inserçăo da primeira delas, na página 132, que apresenta a figura de um senhor bastante idoso, sentado em uma poltrona ao lado de um telefone, o narrador diz sentir uma necessidade muito grande de criar memória para reconstruir sua vida, e que o fará através da recuperaçáo da história do bisavô. A foto vem impressa entre marcaçóes tipográficas que, no livro como um todo, separam as partes de um capítulo. Parece, portanto, que somos convidados a fitar a imagem como se estivéssemos a ler um trecho do capítulo. Após essa primeira foto de seu avô, o narrador contará de suas riquezas, acumuladas por meio de uma empresa de comércio intercontinental. Por náo ter conseguido encontrar mais informaçôes sobre esta história, e, portanto, diante da impossibilidade de acessar como fora o fim do pequeno império do avô, o narrador afirma:

Empresa de transporte marítimo dele de repente năo valia nada. Fui até Santos para ver se arranjava algum registro do que poderia ter sido feito com os navios, mas quando vi que, outra vez, teria que me esforçar muito, desisti. Para o romance Divórcio, entăo, meu bisavô afundou os maiores três cargueiros de sua empresa. (LISIA, 2013, p. 135) 
Figura: Foto extraída do romance Divórcio

momentos todos de felicidade que agora não me voltam à memória, eu devia dizer sim.

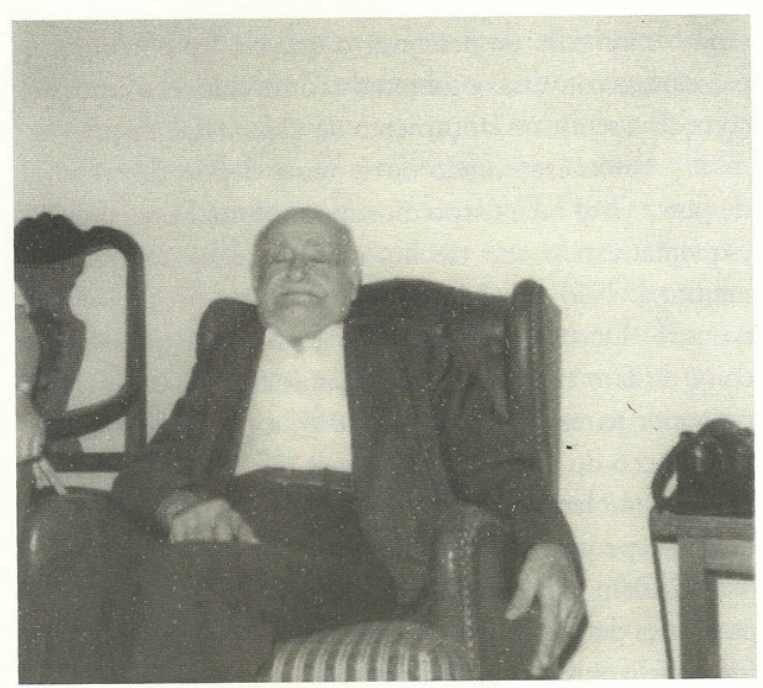

Um mês antes do casamento, chamei dois amigos da época da faculdade para almoçar e dividi entre eles os livros que eu e minha ex-mulher tínhamos iguais. Também doei todos os meus eletrodomésticos. Como ela me dava roupas de presente o tempo inteiro, joguei fora quase todo o meu guarda-roupa antigo.

Da vida que tinha antes de me apaixonar por minha ex-mulher, sobraram-me apenas os livros que vieram para o galpão. Pensando friamente, agora que já tenho

132

Fonte: romance Divórcio, pág. 132

Quando o autor diz "para o romance Divórcio" em seu enunciado, abre um espaço mental que nâo somente faz referência à obra sendo lida, mas sobretudo a um espaço de dúvida proposto ao leitor: o que até este momento foi escrito e inventado para o romance, e o que equivale ao que o escritor quer fazer parecer real? Esta incerteza transfere-se para a observaçăo das imagens impressas no livro. 
Percebe-se, portanto, que a relaçâo que o romance estabelece com o real passa também por uma concepçâo de fotografia como documento. Lísias coloca em debate o conceito mesmo de documento, forçando uma provocaçấo ao leitor com respeito à dinâmica entre palavra e imagem. As fotos em que ele năo está presente podem ser, a rigor, de qualquer pessoa; mas, num primeiro momento, e levados pela deduçấo implicada na obra, as assumimos como "verdadeiras" imagens dos parentes do escritor Ricardo Lísias, por exemplo. Na maior parte dos casos nada prova a favor ou contra, mas o próprio romance acaba por nos induzir à reflexáo sobre nossa relaçáo com as imagens: cotidianamente assumimos que a fotografia é intrinsecamente documental, enquanto o próprio romance demonstra que podemos manipulá-la em diversos níveis, em favor do discurso desejado.

Ou seja, as fotografias de Lísias náo contêm em si a transgressăo da leitura, pois obedecem a um formato fotográfico bastante difundido, a saber, a fotografia de família, íntima, afetiva, elemento fundamental da construçăo das memórias familiares de todos nós. Seu dado transgressor está em sua inscriçâo em um romance autoficcional: um gênero fictício baseado em informaçôes dadas como reais - pela estética do gênero como um todo - cuja força expressiva está justamente em se basear na ambiguidade do pacto de leitura. $\mathrm{O}$ fato de o leitor ter de transitar entre um lugar e outro - pois o texto o leva a isto - traz à tona questionamentos sobre o que é literatura, o que é ficçâo, o que é autoria. E a imagem fotográfica, parceira da palavra neste projeto artístico, recebe o mesmo tratamento de estranhamento no acontecimento da leitura. As fotografias acompanham este modo de leitura que é proposto pelo romance.

Esta forma de conceber a ficçâo literária e a imagem técnica nela contida pode ser tomada como equivalente à instauraçâo de um novo modo de leitura ou, em outros termos, como uma espécie de novo ritual de percepçăo. Martoni \& Ulm (2016) chamam atençấo ao ritmo que novos meios impóem aos corpos, recuperando o pensamento de Vilém Flusser de que o agir e o querer humano săo tecno-culturalmente codificados, para propor o que chamam de "ritual da percepçáo". Dizem eles:

Com essa expressáo, queremos apontar que: 1) nossa percepçăo está condicionada, na verdade, por um conjunto de regras práticas que temos de repetir cotidianamente para que as coisas apareçam; e 2) năo há percepçâo "privada", significando que ela é sempre um fato coletivo de crença. (MARTONI; ULM, 2016, p. 176)

Poderíamos assumir que estaríamos fadados a ler as obras de uma determinada maneira, a fitar a imagem de um determinado modo. A literatura vive entre padróes do dispositivo literário, um modo de organizaçăo culturalmente fabricado que inclui o livro, os gêneros, a autoria, o mercado editorial etc., e o imaginário, uma disposiçăo humana para a ficçăo. Entre elas, e nelas, está o corpo/sujeito que lida com a violência que é nascer em uma cultura (SPIVAK, 2005) e se privar de muitas capacidades humanas. Mas o fictício e o imaginário sâo disposiçōes cotidianas, responsáveis pela possibilidade mesma de comunicaçăo e convívio entre os seres humanos. Fosse diferente, leitores năo se engajariam num fingimento que se realiza plenamente, tal como acontece com um romance ou um filme. Por isso, é muito mais difícil para o receptor aceitar a mescla entre ficçâo e realidade do que aceitar entrar no universo fictício. Hoje, numa época 
em que a vida real é cada vez mais virtual, indistinta desta, acreditamos na hipótese de que os tapas e beijos entre ficção e realidade sejam o grande questionamento das artes na contemporaneidade, que veem com mais clareza novas formas de contaminaçấo entre um e outro regime. E o săo justamente porque tais contaminaçóes nos deslocam a espaços novos, cujos efeitos obrigam a uma adequaçăo da percepçăo com respeito aos modos de leitura, formas de perceber o mundo. 


\section{Referências Bibliográficas}

BELTING, Hans. Por uma antropologia da imagem. Concinnitas, Rio de Janeiro, v. 1, n. 8, jul. 2005.

BLANCHOT, Maurice. 0 espaço literário. Rio de Janeiro: Rocco, 2011.

FOUCAULT, Michel. A pintura de Manet. Visualidades, Goiânia, v. 8, n. 2, jul.-dez. 2010.

ISER, Wolfgang. 0 ato da leitura. Uma teoria do efeito estético. Săo Paulo: 34, 1996. v. 1.

Atos de fingir.

O fictício e o imaginário: perspectivas de uma antropologia literária. Rio de Janeiro: EdUERJ, 2013.

LÍSIAS, Ricardo. Divórcio. Rio de Janeiro: Alfaguara, 2013.

MANDELSTAN, Osip. Conversazione su Dante. Genova: Il Melangono, 2015.

MITTELBERG, Irene. Balancing acts: image schemas and force dynamics as experiential essence in pictures by Paul Klee and their gestural enactments. In: DANCYGIER, B.; BOKRENT, M.; HINNELL, J. (Eds.). Language and the creative mind. Stanford: Center for the Study of Language and Information, 2013. pp. 325-346.

MARTONI, Alex; ULM, Hernán. O gesto de ouvir música em Vilém Flusser: tecnologias de áudio e rituais da percepçăo. Revista Eco-Pós, Rio de Janeiro, v. 19, p. 189, 2016.

SPIVAK, Gayatri Chakravorty. Traduçăo como Cultura. Ilha do Desterro, Florianópolis, n. 48, jan.-jun. 2005. 